\title{
The Passionate Pastor: The Cultural Performances of the Reverend Rutherford Waddell
}

\section{JOHN STENHOUSE}

This article explores some connections between church worlds and cultures of performance in Victorian New Zealand. My examples are drawn mainly, though not exclusively, from the career of a Dunedin Presbyterian minister, Rutherford Waddell. His performances in the pulpit, on the public platform and with the pen made him perhaps the best-known and most influential Protestant minister in the country between the late 1870s and the 1930s. A sermon he preached to his St Andrew's congregation in October 1888, "The Sin of Cheapness", exposed the exploitation of women workers in the clothing industry, galvanizing the emergence of a powerful and broad-based social reform movement on which the Liberal party rode to power in 1890. Passing worker-friendly industrial and labour legislation, and granting the vote to women in 1893, the Liberals won New Zealand an international reputation as the social laboratory of the world. New Zealand Truth, the country's most popular weekly newspaper, testified to the breadth of Waddell's popularity in 1927 when it praised him as a "scholarly, broad-minded man ... idolized by all" who dedicated his life "to elevate, to live justly and to help the fallen." Coming from a paper that normally ridiculed "wowser" parsons - and Waddell was a prohibitionist — this was high praise indeed.

What made Waddell such an effective performer in the pulpit, on the public platform, and with the pen? What enabled him to win admiration and respect even from newspapers such as Truth, normally hostile to causes such as prohibition and female suffrage that Waddell championed? What made certain ministers abler and more compelling performers than others? Might a case study of Waddell shed new light not only on the life of a gifted minister but also on the wider culture within which he operated, illuminating the kinds of Christianity that appealed as well as those that did not? I focus on these questions in what follows.

For a minister, performing well probably mattered more in a New World society such as New Zealand than in the Old World, where privileged and prosperous established churches tended to produce a comfortable, and sometimes complacent, clergy. In the United Kingdom, ministers in the established Anglican and Presbyterian churches could carry out their duties and receive a stipend without having to worry too much about what lay people thought of their performance. A poor preacher or lazy pastor could get away with it. ${ }^{2}$

In New World societies such as the United States or New Zealand, by contrast, no established church existed. Religious institutions became voluntary associations that nobody was forced to attend. Such "free market" religious cultures tended to produce more energetic and adaptable religious professionals more oriented to the needs and concerns of their congregations and the wider culture. A minister, priest or rabbi who failed to perform might find his congregation dwindling, whereas a dynamic preacher or dedicated pastor might attract people from far and wide. ${ }^{3}$ Waddell, as we shall see, drew people from all over Dunedin to St. Andrew's and influenced many more by his writings and speeches. His determination to keep the church in vital touch with a rapidly changing wider culture made him attentive to the concerns of women, the working classes and the poor.

\section{Southern Presbyterians}

One issue must squarely be faced at the outset. Southern Presbyterianism might seem at first sight an unpromising context in which to study cultures of performance. Inspired by Thomas Chalmers' neo-Calvinist vision of building a "godly commonwealth," Scottish Free Church Presbyterians founded the Otago settlement in 1848. ${ }^{4}$ These "Old Identities," led by Captain 
Cargill and the Rev. Thomas Burns, soon won a reputation amongst critics as dour and domineering Calvinists, suspicious of play-acting and pleasure-seeking. On the settlement's first anniversary in 1849, for example, Burns called the community together for a solemn day of thanksgiving, prayer and humiliation before God. The so-called "Little Enemy," led by English Anglican officials appointed by the governor, celebrated instead by staging horse races, water sports and a ball. ${ }^{5}$ Refusing to kowtow to the kirk, they performed their independence culturally.

The arrival in 1861 of a flood of mostly young male gold miners, often Irish and Catholic, exacerbated such tensions. The goldfields minstrel Charles Thatcher, raised in an English Methodist family, composed a song, "The Old Identity," that mocked the Free Church pioneers as dull, domineering sticks-in-the-mud. Performed in hotels from Dunedin to the Dunstan, it became a hit with the "New Iniquity," who roared along with Thatcher and his wife, Annie. ${ }^{6}$

Undaunted, the "Old Identities" continued their campaign to build a godly society. The Rev. Dr D. M. Stuart from Knox Church, a warm-hearted and popular minister, regularly preached on Sunday afternoons to newly arrived miners living in tents and shacks around the bottom of High Street. Meeting at first in a canvas tent and then in a small wooden church, the congregation was formally constituted as St Andrew's parish in $1863 .^{7}$

The gold rush, pumping millions into the Otago economy from 1861, turned Dunedin into the largest and richest city in the country. Churches and cathedrals sprouted beside banks, breweries, bakeries and brothels. Thomas Bracken, an Irish poet and aspiring politician, assessed the performance of city preachers in 1876, identifying earnestness, sincerity and clarity as their main virtues. Yet even the best, such as Dr Stuart and the Rev. A. R. Fitchett of Trinity Wesleyan, displayed defects in diction, tone, style or content. Dunedin could boast no really outstanding pulpit performer. ${ }^{8}$

In 1879 a young Irish Presbyterian minister who had been working in Canterbury since 1877 stepped in to serve as a temporary replacement at St Andrew's. Bracken described its previous minister, the Rev. John Gow, as a "zealous Calvinist" whose "sincerity and earnestness compensate for his lack of elocutionary display." "Waddell's preaching, by contrast, electrified the congregation. Pouring out onto Walker Street after a riveting sermon, members took the unusual step of issuing a call on the spot. St Andrew's had hired a performer. ${ }^{10}$

Economically and ethnically diverse, Waddell's new parish included some of the city's wealthiest and most influential families, living in handsome houses on upper High Street, as well as many poor people, living in cottages and slums in and around Walker Street. Locals called the triangle bounded by Maitland, MacLaggan and Princes Streets the Devil's Half Acre, the city's red-light district. St Andrew's parish boundaries included many Irish Catholics, Lebanese Catholics and Orthodox and much of the city's Chinese population. Originating as a mission church under Dr Stuart, St Andrew's largely retained that identity during Waddell's 42-year ministry. Like Chalmers and Stuart, Waddell worked hard to keep the church in vital contact with the whole of society, not just churchgoers. His career, especially its most controversial aspects, cannot be understood separately from his neoCalvinist vision of building a godly society that looked after the little and lowly as well as the good and great.

\section{Pulpit and Platform Performance: Waddell as Preacher}

International scholarship has explored important interconnections between the pulpit and the stage, acting and preaching, in evangelical Protestant cultures. George Whitefield, the most popular Anglo-American preacher of the eighteenth century and the first mass revivalist in the English-speaking world, preached in Britain and her North American colonies to audiences 
that eventually numbered in the millions. An actor as a young man, Whitefield fused together "a public amalgam of preaching and acting that held audiences spellbound." While "damning contemporary theatre as the 'devil's workshop' on the one hand, he co-opted its secrets and techniques" to become an "actor-preacher" whose performances proved "so powerful and compelling in their emotional intensity that none-including his greatest enemies in the church and theater - could stay away." Whitefield's acting talents and booming voice could move to tears vast outdoor audiences. Although Philadelphia polymath Benjamin Franklin tended to be skeptical of popular piety, he forged a friendship with Whitefield that grew closer and more intimate as they aged. ${ }^{11}$

Waddell had too many physical impediments to rival Whitefield as an actor-preacher. Contemporaries described the Irishman's speaking voice as accented and difficult for strangers to catch. Although he could move audiences powerfully, as we will see, he seldom thundered or pounded the pulpit in the manner of a revivalist preacher. He grew increasingly deaf as he aged, relying on an ear trumpet, which he sometimes found it expedient to mislay. ${ }^{12}$

But assets offset these handicaps. He learned some lessons early. Born and raised in County Down, the heartland of rural northern Irish Presbyterianism, Waddell sat through many church services, sometimes led by his father, a busy minister. Bored by church, Rutherford focused as a teenager on "self-pleasing and enjoyment." The great Ulster evangelical revival, beginning in 1859, passed him by. At the age of 18 , however, a sharp sermon by a passionate preacher in a country church sparked a spiritual crisis, which led him to study for the Presbyterian ministry. He never forgot the lesson, often reminding New Zealanders of a northern Ireland elder's reaction to a boring preacher: "It will be a long time before that man makes the de'il swat, onyway." Taking these experiences to heart, Waddell spoke and wrote with sincerity, conviction and passion. If "you impress people as not having much interest in your subject," he reflected, then "they will take you at your word and not have much interest in it either." Waddell made effective use of the perlocutionary (feeling-changing) and illocutionary (action-inducing) force of language. Whether in the pulpit, on the platform, or with the pen, he wielded words to move hearers and readers to new ways of feeling, thinking and acting, as we will see. ${ }^{14}$

Like his Presbyterian ancestors, Waddell took a "plain and reverential" approach to worship, with the sermon the centerpiece of the service. Ministers familiar with international pulpit performers considered Waddell "the finest preacher we ever knew." During his ministry, St Andrew's attracted crowded congregations from all over the city, drawn by "a common interest in the preacher and his way of presenting the truth." An "expectant stillness" greeted Waddell, "dark-haired and slightly built," as he walked "quietly round the choir seats" to the "open platform with simple rail and reading desk that formed his pulpit." Speaking with "impassioned directness," he preferred "short, direct" sentences to "involved expression"; clarity and directness made his sermons accessible to a socially mixed congregation. If his fondness for quoting poets, novelists, philosophers and theologians appealed to the educated, his puritanical disdain for "artifice," the "superior pose," and "mere showiness" appealed more broadly. Reinforcing speech with "dramatic gestures," he moved hearers. The stories he often told from the pulpit, funny as well as sad, "held the congregation spellbound." One student "remembered all his days the breathless silence of the congregation" at the end of one powerful sermon. Some disliked what they heard. During the 1890s, a young Dunedin businessman told a friend: "I can't go with you to St Andrew's any more. Waddell's preaching is getting too insistent for me."15

He forged a remarkable relationship with his people at St Andrew's. Although he "never lectured, or scolded, or demanded," the congregation invariably supplied whatever he wanted for the church, "no matter what the amount." When he retired, the congregation 
presented him with a cheque for 200 guineas. Anglican, Roman Catholic, Protestant, Jewish and freethinking leaders delivered eulogies at his farewell, suggesting community respect and admiration had come to extend far beyond Presbyterian circles. ${ }^{16}$ Waddell might be likened to the Rev. Dr D. M. Stuart, whose warm-hearted, inclusive, and communitarian Christianity won almost universal popularity. ${ }^{17}$

\section{Outcast Dunedin and the Sin of Cheapness}

Understanding the impact of his most famous sermon requires attending to the wider economic and political context. Waddell arrived in New Zealand's most industrialized city as a global economic downturn began to bite. After publishing reports on poverty and crime in London and Glasgow early in 1884, the Otago Daily Times carried a two-part report on "Outcast Dunedin" in February 1884, probably penned by Silas Spragg. Although New Zealand faced fewer problems than overseas, Dunedin, too, had its "plague-spots." In a "small nest of misery" off Stafford Street the reporters found a "young Irishwoman," poor, disheveled, drunk and sarcastic. Nearby, the Devil's Half-acre contained "the most criminal and degraded members" of the city's population, crowded into "small and squalid huts" for which landlords charged "preposterously high rents." 18 Fitting the pattern of the "humanitarian narrative" identified by historian Thomas Laqueur, "Outcast Dunedin" aimed to spark moral concern and practical action. ${ }^{19}$ Many of the problem areas lay within St. Andrew's parish boundaries.

Public anxiety that New Zealand had not left behind Old World evils began to bubble. In 1887, wages fell suddenly in the clothing industry. The following year, warehousemen and manufacturers cut wages again, reluctantly at first, and hired more women and children, especially boys, who cost less than skilled male workers. ${ }^{20}$ Early in 1888 , Waddell delivered a series of lectures on "Social Problems" at St. Andrews Church Hall. In the fourth, on "Socialism," he argued that "the present system" of industrial capitalism was "founded on systematic injustice" to "the working classes.",

In early October of 1888, Waddell delivered to his St. Andrew's congregation the sermon that made him famous. Although no copies of "The Sin of Cheapness" have survived, we can reconstruct its main outlines, if not the actual words, from press reports. Some Dunedin women were working from 8 a.m. until 11 p.m. finishing moleskin trousers at two and a half pence a pair, and earning only two shillings per day. The community's "enormous rage to get cheap things," spurring "excessive competition" between manufacturers to cut prices and costs, drove wages down to or below subsistence level. Everyone, especially Christians, must take responsibility for "the sin of cheapness." Newspapers around the country erupted with articles and letters for and against Waddell's views. ${ }^{22}$

Seeking to mobilize fellow Presbyterians, early in November Waddell urged the Presbyterian Synod of Otago and Southland to oppose "social injustice" by condemning the "sin of covetousness." The "laws of Christ" applied to "commercial and social as well as religious life," he said, and must prevail over "the laws of political economy." Christ's laws would remain "ideal and dreamy" until "people were prepared to undergo great sacrifice" to make them "real" on "every day of the week and in all places of business." Ministers must "bring their people up to the laws of Christ" not "bring the laws down to the people." Determined to build the kingdom of God in New Zealand, Waddell saw a crucial part of that task as preventing any rift opening up between working people and the churches. After long and lively debate, during which a couple of senior Scottish clergy criticized Waddell's views, the Synod passed by 20 votes to six a motion deploring "the existence of the 'sweating' system in the colony" and instructing "ministers and office-bearers to discourage it by every means in their power." Far from privatizing faith, Waddell and most of the Synod gave it potent public and this-worldly meaning. ${ }^{23}$ 
If middling and working-class Presbyterians played leading roles in the anti-sweating campaign, it quickly won support from across the religious spectrum. Writing in the Tablet, Bishop Moran, whose mostly Irish flock contained many working-class people, condemned the "sin" of "defrauding the labourer of his hire," and denounced the "sweating system" as "deplorable beyond description." 24 Condemning sweating as a "great injustice" to "many in the working classes," the national Wesleyan Conference called for some "well-considered measure" to protect working women from "totally unremunerative" wages. ${ }^{25}$

On 15 February 1889, Waddell called a public meeting in the Athenaeum Hall attended by politicians, clergy and laypeople, including "a large number of ladies." The Presbyterian-dominated committee the meeting appointed to negotiate with employers, chaired by William Downie Stewart from Knox Church, included Waddell, Mrs Rachel Reynolds and Miss Winifred Bathgate, all from St. Andrew's. ${ }^{26}$ Working hard over the following weeks, the committee identified minimum wage rates as the best solution. Employers individually agreed not to hire any contractor who did not pay the minimum wage.

Soon four major warehousing firms got together. Disclaiming any desire to "screw down the workers," they argued that unless the minimum wage rates operated throughout the country, Dunedin firms could not compete. In May, they wrote to the committee refusing to require their contractors to pay minimum wages, and suggesting that Waddell's committee "deal directly between contractor and worker."27

Waddell called another public meeting. On the platform of a packed Choral Hall on the night of 7 June, beside Waddell's committee, sat Otago Daily Times editor George Fenwick, left-liberal politician Sir Robert Stout, populist mayor Henry Smith Fish and a dozen other Dunedin politicians, unionists, business leaders and clergy. Waddell began politely, acknowledging that the four warehousemen had "very courteously received" his committee, promised to "aid us as far as possible," and agreed to pay minimum wages. But although "estimable gentlemen individually," once "they got their heads together" as a group, "they refused collectively to do" what each had promised on his own, without supplying any reason for this sudden change of heart. To those who argued that minimum wages were "unworkable" Waddell replied that they were already working perfectly well in Melbourne. ${ }^{28}$ By speaking courteously, and appealing to reason and evidence to support his case, Waddell was making it hard for critics to dismiss him as a religious fanatic.

But he refused to privatize his deepest convictions. The second half of his speech, bubbling with moral passion and biblical language, suggested that his address at the Choral Hall resembled his preaching at St Andrew's; as sites for cultural performance, the pulpit and the platform overlapped. Waddell charged the warehousemen with being "indirectly involved in the iniquities of a system which we all deplore, and which they themselves profess to abhor." The crowd applauded. The warehousemen had set "an example of selfishness and narrowness unworthy their position." He then identified by name the four firms responsible: Ross and Glendining; Bing, Harris and Co.; Sargood, Son, and Ewen; and Butterworth Brothers. At least two of these, Ross and Glendining, were prominent Presbyterians. If they sustain this "iniquitous system of sweating," said Waddell, "I say these warehousemen will morally occupy a position almost, if not altogether, analagous [sic.] to the receiver of stolen goods. ... I charge these warehousemen with caring more for money than for men." The audience repeatedly applauded. That a prominent Presbyterian minister was willing publicly to rebuke wealthy members of his own church probably enhanced his spiritual stature in the eyes of a wider community that disliked religious hypocrisy. ${ }^{29}$

Treating his audience as if it were a Christian congregation, Waddell then asked if, after 18 centuries "of professed worship and service" of "the greatest master of the human heart," they were willing to "permit in our midst a system that in this young fair land threatens to reproduce here ... those very evils that are eating the heart and soul out of the older 
countries." Shall we "sit down here and allow it to suck the souls out of the lives of our women and girls"? He concluded by urging the meeting to "take this system" of sweating, "with all its aiders and abettors, [and] place them high up on the pillory of public opinion for all men's scorn-yea, till the very geese take courage and hiss derision at them!"

The crowd responded to this morally charged Christian nationalism with "loud and continuous applause." The next speaker, Stout, observed that Waddell had moved the meeting so deeply that it would have passed "almost any resolution" he cared to propose. Confirmation came from the only speaker prepared to dissent. Frederick Fitchett, a lawyer who represented Dunedin Central in parliament, condemned the "feverish enthusiasm" with which Waddell had "preached a crusade." Hoping to marginalize the minister as a fanatic, Fitchett said that idealists who "run their heads into the clouds ... must inevitably come to grief" with "vain" proposals to regulate wages "by act of Parliament." Some members of the audience agreed, shouting "Hear, hear." 30

Every subsequent speaker defended Waddell. Henry Shacklock, a Congregationalist businessman, won laughter and applause by dismissing Fitchett's views as "simply the defence of the warehousemen." George Fenwick named the particular firm and manager leading the "offending." Jewish businessman Bendix Hallenstein thanked Waddell for stirring up "public indignation" and said that "we would prefer to abandon our business rather than carry it on, if it can only be made remunerative by starvation wages. I, for one, would not feel happy to live on the misery of others." Expressing "no sympathy" with Fitchett's views, populist politician Henry Smith Fish said that the four offending firms fully deserved "the censure of the community." Several speakers seconded Waddell's calls for the establishment of a government commission of inquiry and female trades unions. ${ }^{31}$

Hundreds joined the country's first female union, the Tailoresses, over the following days. From July 1889, Waddell served as its first president, working with Harriet Morison, an Irish Methodist, the country's leading female unionist. In 1890 the Atkinson government appointed Waddell to its Sweating Commission, whose report found that sweating as it existed in London and elsewhere did not exist in New Zealand. Unconvinced, Waddell penned a minority report, signed by three commissioners, insisting that "abundant evidence" of sweating existed here. ${ }^{32}$ John Ballance's Liberal party rode the wave of popular enthusiasm for social reform stirred up by Waddell to victory in the general election of 1890 . The Liberals passed labour and industrial laws that made the country a model of progressive legislation.

What made Waddell such an effective performer, able to spearhead a reform movement that brought together all classes and creeds (and unbelievers) in an alliance that packed a powerful political punch? His Irish background provides clues. His mother died when he was too young to remember her. A shy, sensitive, anxious boy, Waddell attended a one-room country school run by a one-armed Roman Catholic, an "all-supreme dominie," who beat pupils with a wooden ruler and then tried to comfort those from well-to-do families. Waddell grew "so afraid of doing anything wrong" that he "lost all originality and initiative," and spent the rest of his life "battling" this "nightmare." 33 Leaving school at 14, he worked long and hard for little for four years as a draper's apprentice in Banbridge. Waddell never forgot these youthful experiences of loss, suffering, cruelty and exploitation. Carried into adulthood, they help explain his ability as a minister to identify and empathize with the little, the lowly, victims, and the poor, which his reading of the Bible reinforced. He disliked domineering people and exploitative systems, and was prepared to do something about them. In a predominantly Protestant culture, where even Freethinkers pounded the pious with Scripture, Waddell's willingness to deploy the language of the Bible against a cruel, ungodly and inhumane system mobilized a powerful response across the religious-and-political spectrum. He set out to move hearers, and did so. 
Yet he was no narrow or exclusive Presbyterian, willing to work only with those who believed and behaved exactly as he did. A second secret of Waddell's success lay in his ability to forge alliances with a wide range of people well beyond his own denomination. As well as Presbyterians, Anglicans, Methodists, Baptists, and Congregationalists, supporters included the Irish Catholic bishop of Dunedin, Jewish businessmen and community leaders, and Robert Stout, the country's leading freethinker. An astonishingly ecumenical antisweating campaign drew support from all parts of the religious, secular, and political spectrum.

\section{The "Other"}

Waddell's openness to and sympathy for a wide range of "others" also had roots in his Irish background. He studied for the ministry at the Presbyterian Theological College in Belfast between 1873 and 1875, when the Victorian crisis of faith was peaking. As he wrestled with the challenges of science and critical biblical scholarship, he came to dislike the authoritarian style of Robert Watts, professor of systematic theology, who "rammed down the throats" of students the conservative Calvinist orthodoxy of Princeton's Charles Hodge. Waddell responded warmly, by contrast, to a kindly, open-minded, young-at-heart Presbyterian minister who "talked with him, not at him or over him," and lent him books. George Eliot's Adam Bede, with its empathic understanding of the spiritual lives of ordinary people, moved Waddell deeply, opening "another world" of "mental and moral insight," marking a "turning point." "34 Eliot became his favourite novelist, on whom he often lectured in New Zealand, though he made it clear that he did not share her agnosticism.

Similarly, although well aware of Robbie Burns's love of whiskey and womanizing, Waddell defended Scotland's National Bard against religious critics. Elected president of the students' Theological Society in 1875, Waddell, who earned an M.A. in English literature at Queen's, urged theologians to take seriously the dreams and visions of poets and novelists. When a pious acquaintance denounced Burns as a "drunken sot," Waddell rejected this "inconsiderate description," insisted that Burns drank from a "deeper source of inspiration" than drink, and hung a picture of the poet above the couch in his college room. ${ }^{35}$

In Dunedin Waddell forged friendships with all sorts of people at or beyond the margins of Christianity. As we have seen, anti-sweating won support from Jewish businessmen and community leaders such as Bendix Hallenstein and George Joachim. Waddell and Rachel Reynolds worked with Mark Cohen to establish the country's first free kindergarten. Although Waddell wanted the kindergarten, open to all, to be based at St. Andrew's, Cohen convinced him to establish the Kindergarten Association on a broader, nondenominational basis. ${ }^{36}$ Waddell regularly invited Robert Stout, the country's leading freethinker, to lecture to the St. Andrew's Literary Society. ${ }^{37}$ The two men worked together on anti-sweating, prohibition and female suffrage.

Waddell shared a long friendship with fellow Irishman Thomas Bracken, a poet, journalist and politician, whose poetry he admired. Their friendship offers insights into the style that made Waddell popular. In 1889 the minister chaired a Friday night lecture by Bracken titled "An apology for bores" that attracted a "very large audience" to Dunedin's Choral Hall. Waddell introduced his friend by saying how fitting it was that "a parson, who had a prescriptive right to be a bore for one day of every week, should preside at an apology for bores." 38 Self-deprecating humour served Waddell well in an egalitarian culture that had no time for pompous clergy. Bracken felt ambivalent about the churches, and, after his marriage failed, lived alone and in poor health behind the Mornington tram sheds, eventually dying penniless in 1898. Waddell and St. Andrew's parishioners "visited frequently." 39

As the Bracken lecture suggests, Waddell liked telling stories, and did not see humour as beneath the dignity of a minister. In May of 1900 he lectured on "Irish Humourists" to a 
record audience that crammed the Church Hall in Walker Street. In lilting tones he told stories about ordinary Irish people-beggars, soldiers, servants and peasants - highlighting their fondness for fighting, whiskey and witty repartee. The Otago Daily Times reported that Waddell kept the crowd in "a state of great merriment," repeatedly "convulsed with laughter," for "almost two hours." "Though certainly puritanical, as we shall see, Waddell was a humane and down-to-earth puritan who liked to enthral an audience. Many found the style of his performances as appealing as their substance.

\section{Women}

Women played an important symbolic role in Waddell's attack on sweating as a diabolical system that "sucked the souls" out of "our women and girls." He identified the treatment of women and girls as a key sign of what he believed could and should be the new nation's difference from and superiority to the Old World. Campaigning to save women and girls from "white slavery," as Presbyterian politician William Downie Stewart called it, and to make New Zealand a shining example to the world, enhanced the unity and effectiveness of the anti-sweating campaign precisely because people of all creeds and none could - and didembrace such values.

The following section, focused on Waddell's relationships with women, combines the old "top down" approach of traditional church history, focused largely on male leaders, with the "bottom up" perspective of more recent religious history, focused on ordinary people. Without friends, colleagues and supporters, even gifted clergy such as Waddell would have made little impact. Ministers needed to understand and respond to the needs and concerns of the public in order to mobilize support. Taking a dialogical approach that combines both perspectives, I argue that women helped make Waddell's life and career from beginning to end.

Writing in 1920, Waddell identified the pious "aunt who was a mother to me" after his birth mother died as "the saving of me as of so many others" during his early years in Ireland. He credited this aunt, strict and loving, with creating the "godly home" in which he grew up. $\mathrm{He}$ made no mention of his father, a busy Presbyterian minister. ${ }^{41}$ On trips back to Ireland from New Zealand, he never failed to visit his "mother."

On 27 January 1877, in Dublin, he married Kathleen Newman. Their only child, Muriel Alice Newman, was born in Dunedin on 28 April 1882. The marriage appears to have had its tensions. Waddell, slightly built, worked hard, often spending eight hours a day or more in his study early in his ministry, with pastoral visiting and public speaking on top of that. Pushing himself to the limit, he had to take sick leave in 1882, 1886, 1902 and 1913. Did a lonely and sometimes traumatic childhood, without a close relationship with either biological parent, make intimacy difficult, leading him to throw himself into his work? Kathleen, homesick for family and friends in Ireland, suffered badly from rheumatism, eventually becoming a chronic invalid. She died in Seacliff Mental Hospital in 1920. Waddell's biographer records "how deeply he felt for her." The Rev. James Gibb, his close friend, considered that Waddell had "a larger share" of "the trials of life" than "comes to most men." ${ }^{42}$ Little evidence has survived of how Kathleen felt about their marriage. Tensions at home may have encouraged Waddell to pour his energies and talents into his ministry. He was by no means the only Protestant religious leader to do so. ${ }^{43}$

Waddell forged important relationships with women as soon as he arrived at St. Andrew's. In 1880 he established a Ladies Literary Society. In April 1881, at a congregational soirée, St. Andrew's women, evidently impressed by their young Irishman, presented him with a gift of fifty pounds. ${ }^{44}$ At the Walker Street mission hall, opened in 1888 , Waddell set up a savings bank, a free library, and the country's first free kindergarten, intending all three 
to assist working people, especially women. In establishing the kindergarten, he worked closely with Rachel Reynolds of St. Andrew's and Jewish journalist Mark Cohen.

Reynolds and her husband William, a businessman-politician, had been instrumental in founding St Andrew's. Pillars of the parish, and champions of high school and university education for women as well as men, they worked closely with Waddell in several causes. From the beginning of his ministry, Waddell made space for women to exercise their performative talents in public places. In April 1888, for example, he invited Rachel to be the main speaker at a special meeting in St Andrew's Hall to raise money for poor people "striving to better themselves." Received with "hearty applause," Reynolds entertained a good crowd for 90 minutes about a solo trip she had made eight years earlier to visit her brother in the United States. ${ }^{45}$

In 1885 Waddell was one of four ministers present at the founding meeting of the Dunedin Women's Christian Temperance Union (WCTU). ${ }^{46}$ Led and numerically dominated by Presbyterian, Baptist and Methodist women such as Reynolds, Catherine Fulton, Mary Downie Stewart, and Harriet Morison, the WCTU campaigned for temperance, Bible in Schools, raising the age of consent, and the vote. During the late-1880s, Rachel and William Reynolds played prominent roles in Waddell's anti-sweating campaign. William called for a "committee of energetic women" to take the lead in stopping the "evil," while Rachel joined Waddell's anti-sweating committee and, with Waddell and Morison, founded the Tailoresses Union.

Morison, Reynolds and Waddell also worked together in the temperance and female suffrage campaigns of the early 1890 s, which proved more divisive than anti-sweating. Born in Ireland to a master tailor and his wife, Morison served as a lay preacher for the Bible Christians, a democratic and working-class offshoot of Wesleyan Methodism. This prepared her well for the suffrage campaign. Addressing a crowded public meeting in Dunedin's Choral Hall in July 1891, Morison spoke for "a very large number of working women ... who earnestly desired the franchise extended to them, because they felt the need of it." Applause greeted Morison's claim that working women wanted "many reforms," and "would like to have a voice in the return of members to Parliament, who would look faithfully after their interests." Far from inevitably preferring "the Tory candidate," as critics alleged, Morison argued that women, "broad and liberal in their views," would "only vote for those candidates who were pure in their lives and conduct.",47

After four more Protestant pillars of the community-Alexander Bathgate, Mary Downie Stewart, James Allen and Frederick Chapman-supported suffrage, Rachel Reynolds took the floor. Aware that anti-suffragists sometimes quoted Scripture to justify female subordination, Reynolds set out to show that "woman had a right to equality with man in the very nature of things" by showing that Genesis, "the first and oldest constitution about which anything was known," supported female equality. Women had for centuries suffered "injustice" through "a misunderstanding and misinterpretation of the fall of man" in Genesis chapter three, she said. After Adam and Eve ate the "forbidden fruit," God cursed "the man," not the woman, and turned "the man alone ... out of the garden." A "great many" people, Reynolds concluded, "would be sufficiently noble to admit that woman had a right not only to be regarded as man's equal but even as his superior." A packed Choral Hall greeted these words with laughter and applause. ${ }^{48}$

Far from rejecting Reynolds's interpretation of Genesis, Waddell, speaking next, dismissed all the arguments against suffrage as "utterly futile" and "wanting singularly in lucidity, in logic, and in sense of justice." The claim that women were incompetent to vote he dismissed as "a relic of the old barbaric theory that woman was lesser than a man, and was not to be counted as a unit in citizenship." Women possessed "as much intelligence and common sense" and as many of "the qualities which were essential in politics" as men. New Zealand 
would "never have fair and true laws for women and children until they got women in the House of Representatives" because on women's, family and children's issues "the judgement of women ranked far higher than the judgement of men." Waddell hoped for the day when "men should have the privilege of voting for women as their representatives." most high-profile Presbyterian minister had resoundingly endorsed the suffrage campaign. Critics noticed.

Suffrage sparked stronger male working-class opposition than anti-sweating partly because of its close links with prohibition, the militant wing of the temperance movement. In 1883, Waddell established a branch of the Blue Ribbon Army at St Andrew's; dozens signed a petition supporting the Local Option Extension Bill introduced into parliament by M. W. Green, MHR for Dunedin East and a Church of Christ evangelist. ${ }^{50}$ In 1889, lauding Methodism as a "people's church" in the "vanguard of progress," Waddell praised prohibition as a humane reform that would help "the mass of the people," especially women and children. $^{51}$

From 1885, the Dunedin WCTU campaigned for prohibition and Bible in Schools as well as the vote, all causes that Waddell championed. The organization's most enthusiastic male supporters included Waddell's friend John Wesley Jago, Congregationalist editor of The Prohibitionist. Extolling the WCTU as "the most wonderful institution ... on the face of this globe," Jago argued there should be "no limitation to woman's sphere" and urged men to hail "with joy and gladness" the willingness of women to join them in regenerating the world. ${ }^{52}$

In 1892 Waddell led the "temperance party," dominated by evangelical Protestants, in a raucous public meeting in the Town Hall convened to discuss the Compensation to Licensed Victuallers Bill currently before parliament. ${ }^{53}$ Leaders of the "moderate" opposition, mostly Anglican, Catholic or Jewish, had forged links with the Licensed Victuallers Association, a politically influential lobby group. ${ }^{54}$ When Jago, manager of the Evening Star newspaper, urged the meeting to reject compensation, ex-publican John Carroll, Dunedin's first Catholic mayor, dismissed Jago's "claptrap" and praised compensation as "fair and just." He might "sympathize" with his opponents, said Carroll, were they not "so aggressive and dishonest." After the "hisses and uproar" died down, Jewish brewer Maurice Joel, supporting Carroll, praised the "British nation" for its "liberal ideas" on "justice to all." He had gone into brewing, said Joel, because it was "just" and "profitable," but, thanks to the prohibitionists, he had already lost 10 to 15 thousand pounds. ${ }^{55}$

In reply, the Rev. William Ready, a Bible Christian minister who regularly attracted over 1500 people to the Garrison Hall on Sunday nights - probably the largest congregation in the country-urged "the people" to "throw off the shackles of the divine right of brewers" and refuse "to allow a few men who are interested in their trade to rule the thousands of people in this colony": the "British people are not to be oppressed-by publicans." We "have been fighting for the protection of property too much," thundered Ready, echoing Waddell's antisweating rhetoric, "and not enough for men and women." Applause and laughter greeted his conclusion that "all who believe in the grand old Book, should compensate the publicans for all the empty coffins, pawnbrokers' tickets, and drafts on the bank of hell." Ready founded the Methodist Central Mission on Stafford Street, next door to St. Andrew's. Though well educated, Waddell did not disdain working in good causes with evangelicals such as Ready, with a more populist, rough-and-ready style.

The crowd called for Waddell, who made five unsuccessful attempts to speak before the Mayor restored order. He felt "a good deal of pain," said Waddell, in opposing "gentlemen whom he respected," several of whom were "intimate friends." It seemed "a little hard" that licensees should be dispossessed "without getting some compensation." Yet "the interests of a large number of citizens" harmed by drink meant that "he could not support the principle of compensation." Since the law had already reduced the hours during which liquor 
could be sold, how could temperance advocates "be such terrible confiscators if they said that publicans should not sell" liquor not just on Sunday but also "on Monday, Tuesday, Wednesday and Thursday." This sparked "laughter, applause, uproar and cries of "Chair." After being drowned out for several minutes, Waddell stopped trying to speak and sat down. The meeting voted to reject compensation.

Once again, Waddell had mobilized public opinion to promote the common good, as he saw it, without demonizing those with whom he disagreed. The respect he expressed for those involved in the trade went beyond mere rhetoric. His St Andrew's congregation probably included advocates of temperance but not prohibition who liked a wee dram.

\section{Male Critics}

Waddell's outspoken support for prohibition, female suffrage and Bible in Schools sparked fierce criticism from some local labour leaders who had supported the anti-sweating campaign. In July of 1892 Samuel Lister warned readers of the Otago Workman that the "tabbies" leading the franchise campaign had joined forces with their "favourite parson" to lobby for prohibition, Bible in schools and votes for women. This unholy alliance between "male women" and "female men" threatened a man's right to drink and the country's free secular primary school system, "the dearest privilege the children enjoy." 56 To battle the forces of darkness, Lister forged an alliance with populist politician Henry Smith Fish and William Dawson, manager of Speights brewery, whose colleague Charles Greenslade, an Anglican, led the "moderates" against Waddell's "temperance" party. ${ }^{57}$ As chief parliamentary lobbyist for the liquor trade, Fish, who had won working-class support by halving the price of gas during his first term as mayor, described granting women the vote as worse than giving children "razors and revolvers" to play with. He cemented his reputation as chief enemy of the women's movement in 1892 by organizing anti-suffrage petitions that, he claimed, obtained 5000 signatures. But his paid canvassers often presented the first petition as pro-suffrage. In July, Helen Nicol of the WCTU and Sir John Hall exposed Fish's dubious tactics in parliament and the press. ${ }^{58}$

WCTU leaders, furious, urged "every member of our unions" and "every member of our sex, by all that is womanly, to make an indignant protest against the actions of Mr Fish and his allies." took a pro-suffrage petition to the streets. By the time it reached parliament in 1893, a remarkable $57 \%$ of southern Dunedin women had signed it, more than twice as many as the $25 \%$ of adult New Zealand women who signed. ${ }^{60}$ Women affiliated to the evangelical churches, which had many working-class as well as middle-class members, substantially outnumbered Anglican and Catholic signatories. ${ }^{61}$ Unwittingly, Fish turned out to be the feminists' best friend. When he plummeted to defeat in the 1893 election, a vast crowd of women, delighted, "indulged in a war dance, fast and furious, reaching from Garrison Hall to the Octagon.",62

Before the general election of 1892, Robert Slater, secretary of the Trades and Labour Council and a staunch Methodist, announced that the Worker's Political Committee had chosen five Labour candidates. All accepted women's suffrage and the political demands of the New Zealand Alliance. Lister and Fish, furious, fell out and turned on each other. ${ }^{63}$ The parson-feminist alliance, spearheaded by Waddell, Reynolds, Morison, and Nicol, had won considerable support amongst Dunedin's working classes, male as well as female.

\section{Conclusion: the Secrets of Waddell's Success}

Churches played a substantial role in popular cultures of entertainment and leisure between the 1880s and the 1930s partly because fewer alternatives existed than in later periods. Before the rise of the movies and in-home entertainment such as radio, television, video and the 
internet, church-based entertainments - socials, dances, talks, bazaars, fêtes, sports clubs and picnics - attracted large audiences. Churches also played major roles in providing what many Victorians called "rational recreation." As Tony Ballantyne has shown, many of the mutual improvement societies and literary and debating clubs that flourished in Victorian New Zealand were church-based. ${ }^{64}$ Waddell established several such institutions at St Andrew's and, as we have seen, performed compellingly in them. ${ }^{65}$

The performances explored above-sermons at St. Andrew's, exhortations at Synod, popular lectures, and speeches on the public platform-suggest several reasons, mutually reinforcing, for Waddell's success. Youthful experiences of loss, cruelty and suffering in northern Ireland gave him a capacity to identify and sympathize with the little, victims, and outsiders. He never lost the feeling of being an outsider, nor his empathy for those on the margins. This compassion and inclusiveness was reinforced by his neo-Calvinist vision of keeping the church in lively contact with the whole of society, not just the pious and respectable. Secondly, he forged relationships with all sorts of people, within and beyond the churches, which enhanced the breadth and political effectiveness of his reform campaigns. In these, Waddell deployed moral and humanitarian discourse that secular as well as religious people could happily endorse. But he did so as a Christian minister who never hesitated, on the platform as in the pulpit, to invoke biblical and Christian language and images as well. In a city founded by Presbyterians, Waddell's public religiosity enhanced the sharpness, depth and power of his words. Thirdly, he willingly set up the platform for others. As we have seen, the women with whom he worked-Rachel Reynolds, Winifred Bathgate, Harriet Morison, and Christabel Duncan, pioneer Presbyterian Deaconess who became Waddell's second wife-became adroit public performers who helped transform the country's religious, political and economic life. Without them, male reformers would have been crying in the wilderness. Finally, Waddell's performances succeeded because, in style as well as substance, they appealed to popular religiosity. Though highly educated and well read even by Presbyterian clerical standards, Waddell did not set himself apart from and above ordinary folk. In battling for working people, unions, minimum wages, female suffrage and free kindergartens, and against sweated labour and alcohol abuse, Waddell practised as well as preached the kind of down-to-earth, this-worldly, "practical Christianity" that won respect even from those who seldom went to church. ${ }^{66}$

\footnotetext{
${ }^{1}$ New Zealand Truth, June 2, 1927, 6; see also New Zealand Truth, May 24, 1928, 6.

${ }^{2}$ See also Rodney Starke and Roger Finke, Acts of Faith: Explaining the Human Side of Religion (Berkeley and Los Angeles: University of California Press, 2000), 193-217.

${ }^{3}$ Ibid., 218-58.

${ }^{4}$ Stewart J. Brown, Thomas Chalmers and the Godly Commonwealth in Scotland (New York: Oxford University Press, 1982).

${ }^{5}$ A. H. McLintock, The History of Otago: The Origins and Growth of a Wakefield Class Settlement (Dunedin: Otago Centennial Historical Publications, 1949), 276-79.

${ }^{6}$ Robert H. B. Hoskins, "Thatcher, Charles Robert," from the Dictionary of New Zealand Biography, Te Ara the Encyclopedia of New Zealand, accessed March 27, 2013,

http://www.TeAra.govt.nz/en/biographies/1t91/thatcher-charles-robert.

${ }^{7}$ R. J. Eyles, Rutherford Waddell: Man and Parish (Palmerston North: Presbyterian Historical Society, 1986), 1.

${ }^{8}$ Didymus [Thomas Bracken], Pulpit Pictures (Dunedin: Coulls \& Culling, 1876), passim.

${ }^{9}$ Ibid., 56

${ }^{10}$ J. Collie, Rutherford Waddell: Memoir and Addresses (Dunedin: A.H. Reed, 1932), 50-51.

${ }^{11}$ Harry S. Stout, The Divine Dramatist: George Whitefield and the Rise of Modern Evangelicalism (Grand Rapids: Eerdmans, 1991), xviii-xx, 222-33.

12 Collie, Rutherford Waddell, 70-91.

${ }^{13}$ Rutherford Waddell, My Pathway to Christ: A Confession of Faith (Dunedin: New Zealand Bible, Tract and Book Society), 1920, 5-7; Collie, Rutherford Waddell, 27.
} 
${ }^{14}$ J. L. Austin, How To Do Things With Words (Oxford: Oxford University Press 1980), 109-20. For a fuller explanation of perlocutionary and illocutionary force, and of why historians should take speech act theory seriously, see Quentin Skinner, "Interpretation and the understanding of speech acts," Visions of Politics, Volume 1, Regarding Method (Cambridge: Cambridge University Press, 2001), 103-27.

${ }^{15}$ Collie, Rutherford Waddell, 27, 74-77.

${ }^{16}$ Collie, Rutherford Waddell, 64-69, 77.

${ }^{17}$ Margaret Morgan, “The Right Man for his Time: D.M. Stuart D.D.," in Building God's Own Country:

Historical Essays on Religions in New Zealand, eds. John Stenhouse and Jane Thomson (Dunedin: University of Otago Press, 2004), 32-45.

${ }^{18}$ This account is based on the reports appearing in the Otago Daily Times, February 4, 1884, 3 and February $25,1884,3$.

${ }^{19}$ Thomas W. Laqueur, "Bodies, Details and the Humanitarian Narrative," in The New Cultural History, ed. Lynn Hunt (Berkeley and Los Angeles: University of California Press, 1989), 176-204.

${ }^{20}$ R. T. Robertson, “'Sweating in Dunedin, 1888-1890," (Postgraduate Diploma in History, University of Otago, 1974), 1-3.

${ }^{21}$ Otago Daily Times, July 27, 1888, 3.

${ }^{22}$ Otago Witness, October 26, 1888, 27; Otago Daily Times, October 20, 1888, 3; Southland Times, October 22, 1888, 3; Tuapeka Times, October 24, 1888, 2; Star, October 22, 1888, 3; Wanganui Chronicle, October 26,

1888, 2; Poverty Bay Herald, October 29, 1888, 3.

${ }^{23}$ Otago Daily Times, November 8, 1888, 4.

${ }^{24}$ Tablet, 9 November $1888,1$.

${ }^{25}$ Otago Daily Times, February 6, 1889, 3.

${ }^{26}$ Otago Daily Times, February 15, 1889, 2.

${ }^{27}$ Ibid.

${ }^{28}$ Otago Daily Times, June 8, 1889, 2. The following account is based on this report of the meeting, which may be regarded as a general reference.

${ }^{29}$ On popular antagonism to religious hypocrisy, see John Stenhouse, "Christianity, Gender and the Working

Class in Southern Dunedin, 1880-1940," Journal of Religious History 30, no. 1 (2006), 18-45, and especially $38-43$.

${ }^{30}$ Otago Daily Times, February 15, 1889, 2.

${ }^{31}$ Otago Daily Times, June 8, 1889, 2.

${ }^{32}$ Appendices to the Journals of the House of Representatives, 1890, H-5.

${ }^{33}$ Collie, Rutherford Waddell, 22-23.

${ }^{34}$ Collie, Rutherford Waddell, 32-34, 39-41.

${ }^{35}$ Belfast Witness, August 26,1932, n.p. This appears in a miscellaneous collection of newspaper clippings on Waddell contained in St. Andrew's, Dunedin, Historical Papers, miscellaneous, c.1880s-1950s, Presbyterian Archives, Knox College, Dunedin.

${ }^{36}$ Otago Daily Times, December 21, 1891, 3.

${ }^{37}$ Otago Witness, September 14, 1899, 3.

${ }^{38}$ Otago Daily Times, March 21, 1889, 14.

${ }^{39}$ T. C. Coull, Reminiscences, St Andrew's Presbyterian Church Social Hour, 25 November 1951, in St. Andrews, Dunedin, Historical Papers, miscellaneous, c.1880s-1950s, Presbyterian Archives, Knox College, Dunedin.

${ }^{40}$ Otago Daily Times, May 8, 1890, 17.

${ }^{41}$ Waddell, My Pathway to Christ, 5-6.

${ }^{42}$ Collie, Rutherford Waddell, $8,158$.

${ }^{43} \mathrm{John}$ Wesley, the founder of Methodism, is an obvious example; George Whitefield, who never married, illustrates a related dynamic.

${ }^{44}$ Otago Daily Times, April 27, 1881, 2.

${ }^{45}$ Otago Daily Times, April 10, 1888, 2.

${ }^{46}$ Otago Daily Times, May 8, 1889, 2; Dorothy Page, introduction to The Suffragists: Women Who Worked for the Vote: Essays from the Dictionary of New Zealand Biography (Wellington: Bridget Williams Books, 1993), 7.

${ }^{47}$ Otago Daily Times, July 11, 1891, 4; see also Evening Star, July 11, 1891, supplement, 1.

${ }^{48}$ Otago Daily Times, July 11, 1891, 4.

${ }^{49}$ Ibid.

${ }^{50}$ Otago Daily Times, June 30, 1883, 2.

${ }^{51}$ Otago Daily Times, February 1, 1889, 4.

${ }^{52}$ Otago Daily Times, April 22, 1889, 3. 
${ }^{53}$ Leaders of the "temperance party" included Presbyterian businessmen A. C. Broad and A. C. Begg, Methodists Rev. William Ready and William Hatton, Congregationalists Rev. A. H. Wallace and John Wesley Jago, and Baptist lawyer A. S. Adams.

${ }^{54}$ Local leaders of the "moderate" party included Anglicans such as R. L. Stanford and Charles Greenslade of Speights brewery; Catholics such as John Carroll, an ex-publican who became Dunedin's first Catholic mayor; and Maurice Joel, a Jewish brewer.

${ }^{55}$ The following account of this meeting is based on the report in Otago Daily Times, July 6, 1892, 3, which may be regarded as a general reference for the following two paragraphs.

${ }^{56}$ Otago Workman, July 9, 1892.

${ }^{57}$ See further, Erik Olssen, Building the New World: Work, Politics and Society in Caversham 1880s-1920s, (Auckland: Auckland University Press, 1995), 180-3.

${ }^{58}$ Otago Daily Times, July 26, 1892, 3. On Fish, see Kenneth W. Turner, "Henry Smith Fish and the Opposition to the Female Franchise in Dunedin, 1890-93" (BA Hons Long Essay in History, University of Otago, 1985).

${ }_{59}$ Prohibitionist, 1892 (the Hocken microfiche copy lacks issue and page numbers); for a fuller discussion, see Turner, "Henry Smith Fish," 52-59.

${ }^{60}$ Kirsten Thomlinson, "We the Undersigned: an Analysis of Signatories to the 1893 Suffrage Petition from Southern Dunedin" (MA thesis, University of Otago, 2001).

${ }^{61}$ J. Stenhouse, "God, the Devil and Gender," in Sites of Gender: Women, Men and Modernity in Southern Dunedin, 1890-1939, eds. Barbara Brookes, Annabel Cooper and Robin Law (Auckland: Auckland University Press, 2003), 313-47.

${ }^{62}$ Otago Workman, December 2, 1893, 4.

${ }^{63}$ Olssen, Building the New World, 185-86.

${ }^{64}$ Tony Ballantyne, "Thinking Local: Knowledge, Sociability and Community in Gore's Intellectual Life, 18751914," New Zealand Journal of History 44, no. 2 (2010), 138-56.

${ }^{65}$ Cameron W. R. Taylor, "Mirroring Each Other: The Mutual Improvement Movement, Rutherford Waddell and the St. Andrew's Young Men's Mutual Improvement Association” (BA Hons thesis, University of Otago, 2010).

${ }^{66}$ Alison Clarke, “ 'Tinged with Christian Sentiment': Popular Religion and the Otago Colonists, 1850-1900," in Christianity, Modernity and Culture: New Perspectives on New Zealand History, ed. John Stenhouse (Adelaide: ATF Press, 2005), 103-31; Stenhouse, "Christianity, Gender and the Working Class". 